\title{
POSTERIOR SUBCAPSULAR CATARACT FOLLOWING INTENSE ULTRAVIOLET RADIATION EXPOSURE: A CASE REPORT
}

\author{
JULES BAUM ${ }^{1}$ and DONALD G. PITTS ${ }^{2}$ \\ Chestnut Hill, Massachusetts and Houston, Texas
}

\begin{abstract}
SUMMARY
A 46-year-old Caucasian man with no other known risk factors developed bilateral posterior subcapsular cataracts soon after intense exposure to ultraviolet radiation. This case report supports experimental and epidemiological evidence implicating ultraviolet radiation as a risk factor for cataract formation.
\end{abstract}

Ultraviolet (UV) radiation is thought to be one of the risk factors for the development of cataracts. Specifically, exposure of laboratory animals to UV-B (295-320 nm) has been shown to result in cortical cataract $^{1,2}$ and posterior subcortical cataract ${ }^{2}$ (PSC) formation. Epidemiological studies also give weight to UV-B as a risk factor for human cortical cataract ${ }^{3}$ and PSC $^{4,5}$ formation. The case report presented here provides additional evidence to suggest that UV radiation is a risk f $\mathrm{s}$ stor for cataract formation.

\section{CASE REPORT}

A white man was noted to have a PSC in the right eye for the first time in 1976 at the age 46 years. By March 1978 a dense PSC had also developed in the left eye. Cataract surgery was performed in the right eye in April 1978, and in the left eye in September 1979. The patient is the youngest of seven siblings, none of whom, the patient states, is aware of cataract development as of 1993. His mother developed cataracts at age 70 years and his father died at age 85 years with no history of cataract formation. His medical history at that time was negative except for surgical removal of kidney stones. No metabolic abnormality was found. There is no history of significant corticosteroid administration.

In February 1975, while employed as an elec-

From: ${ }^{1}$ Boston Eye Associates, Chestnut Hill, Massachusetts; ${ }^{2}$ Optometry and Vision Science, College of Optometry, University of Houston, Houston, Texas, USA.

Correspondence to: Jules Baum, MD, Boston Eye Associates, 1244 Boylston Street, Chestnut Hill, MA 02167, USA. tronics design engineer and approximately 18 months before the cataract was first observed in his right eye, he helped to design a device known as a photoionisation trace gas analyser. The battery-operated device consisted in part of a hand-held probe which emitted UV radiation. Characteristics of the ion source, as stated in the records, include a wavelength of $120 \mathrm{~nm}$, a power density of $1.0 \mathrm{~W} / \mathrm{cm}^{2}$ and a photon energy of $10.2 \mathrm{eV}$. The patient checked the probe function routinely by viewing the probe tip held within several centimetres of one eye to see whether the probe would 'fire', and characteristically saw a purple glow emitted from the activated probe. He wore no protective glasses or goggles. He used his right eye predominantly, but occasionally used his left eye for testing the probe. Exposure took place between February 1975, and October 1978, during which time he worked with the device for a total of 4-5 months. The eye was exposed to radiation for approximately 10 minutes per test, 6 tests daily, 5 days a week.

The physical characteristics of the ion source allow the calculation of the total irradiance and radiant exposure received from exposure to the ion source. The duration of exposure from the 4-5 month observation of the ion source would be: 22 weeks $\times 5$ days $/$ week $\times 1$ hour $/$ day $=110$ hours or 396000 seconds. The total radiant exposure to the eye was: $H_{\text {eye }}=\mathrm{W} / \mathrm{cm}^{2} \times t=1.0 \mathrm{~W} / \mathrm{cm}^{2} \times 396000$ seconds $=$ $3.96 \times 10^{5} \mathrm{~J} / \mathrm{cm}^{2}$. The conclusion is that this is an extremely high biological exposure. The radiant exposure for 1 hour would be: $H=1 \mathrm{~W} / \mathrm{cm}^{2} \times$ 3600 seconds $=3600 \mathrm{~J} / \mathrm{cm}^{2}$.

\section{DISCUSSION}

Evidence suggesting a causal relationship between UV radiation and the development of bilateral PSC in the present case includes a relatively early age of onset of the cataracts, a powerful source of UV 
radiation emission held close to the eyes intermittently over a course of 4-5 months, an absence of other risk factors, and an alleged absence of cataract formation in six older siblings, each now over the age of 60 years. While the aetiology and mechanism of cataract formation are not fully known, the negative history of cataracts in the family may be an excellent guide as to whether the patient was genetically predisposed to cataracts. The hereditary occurrence of certain types of cataracts in a given family has been well established and there are numerous reports of families showing a high incidence of cataracts over several generations. ${ }^{6}$

The predominant viewing of the ion source with the right eye is clearly demonstrated by the history of the development of cataract. At some stage of the development of the cataract in the right eye, the patient would be expected to change and observe the ion source more frequently with the left eye because he could see better at that point using the left eye. The fact that surgery was performed on the right eye first is not because of the greater total exposure to the right eye but because, at one point in time, vision in the left eye deteriorated to a level where surgery was necessary to restore useful vision, and the eye with the more severe cataract and poorer vision (right eye) was selected for surgery. Indeed, it argues that the total exposure to each eye was not materially different and that the exposure was sufficient to produce a cataract in each eye. The difference in dosage between the viewing and non-viewing eye was the difference between the square of the distance of the ion source and the cosine of the angle of the non-viewing eye - a difference not considered great.

Although the ion source in the present case emitted a primary wavelength of $120 \mathrm{~nm}$, the patient saw the probe glow purple when activated, attesting to fluorescence at higher wavelengths. This purple glow illustrates that the energy from the ion source did penetrate to the retina. Grenz rays at $120 \mathrm{~nm}$ are known to penetrate about $1.0 \mathrm{~mm}$ of soft tissue. With the cornea being $0.5 \mathrm{~mm}$ thick, the ion source penetrated the cornea and passed through the lens and on to the retina. ${ }^{7}$ Data indicate that both the aqueous and vitreous humours transmit UV radia- tion and there is no reason to believe otherwise for the ion rays emitted from the probe, as used by the patient. The action spectrum for the lens is from $295 \mathrm{~nm}$ to $320 \mathrm{~nm}$ with a radiant exposure of $0.15 \mathrm{~J} / \mathrm{cm}^{2}$ at $300 \mathrm{~nm}$. The total ion source exposure experienced by the patient exceeded the cataract threshold level at $300 \mathrm{~nm}$ by a factor of $3.96 \times 10^{5} \mathrm{~J} / \mathrm{cm}^{2} / 0.15 \mathrm{~J} / \mathrm{cm}^{2}=2.6 \times 10^{6}$ or a factor of 2600000 , not an inconsequential number. Further, compare either of the calculated total exposures (see Case Report) with the laboratoryestablished cataract threshold radiant exposure of $0.15 \mathrm{~J} / \mathrm{cm}^{2}$ at $300 \mathrm{~nm} .{ }^{8}$

This single case report serves to document a putative causal effect of intense UV radiation on the development of PSC, expanding past human epidemiological evidence implicating UV-B as a strong risk factor for cataract formation.

Key words: Posterior subcapsular cataract, Ultraviolet radiation, UV-B,

\section{REFERENCES}

1. Jose JG, Pitts DG. Wavelength dependence of cataracts in albino mice following chronic exposure. Exp Eye Res 1985;41:545-63.

2. Zigman S, Graff J, Yulo T, Vaughen T. The response of mouse ocular tissue to continuous near-UVB light exposure. Invest Ophthalmol 1975;14:710-3.

3. West SK, Rosenthal FS, Emmett EA, Abbey H, Munoz B, Taylor HR. Senile eye changes: ultraviolet light and risks of cataract. Invest Ophthalmol Vis Sci 1987;28(Suppl):397.

4. Bochow TW, West SK, Azar A, Munoz B, Sommer A, Taylor HR. Ultraviolet light exposure and the risk of posterior subcapsular cataracts. Arch Ophthalmol 1989;107:369-72.

5. Taylor HR, West SK, Rosenthal FS, Munoz B, Newland HS, Abbey H, Emmett EA. Effect of ultraviolet radiation on cataract formation. $N$ Engl $J$ Med 1988;319:1429-33.

6. Duke-Elder, Sir S, editor. System of ophthalmology, vol II, Diseases of the lens and vitreous; Glaucoma and hypotony. London: Henry Kimpton, 1969:151,156-7.

7. Pitts DG, Cullen AP, Hacker PD. Ocular effects of ultraviolet radiation from $295 \mathrm{~nm}$ to $365 \mathrm{~nm}$. Invest Ophthalmol Vis Sci 1977;16:932-9.

8. Yannuzzi LA, Fisher YL, Krueger A, Slarkter J. Solar retinopathy: a photobiological and geophysical analysis. Trans Am Ophthalmol Soc 1987;85:120-58. 